\title{
Indices of Central and Peripheral Obesity; Anthropometric Measurements and Laboratory Parameters of Metabolic Syndrome and Thyroid Function
}

\author{
Şükrü Aras ${ }^{1}$, Seyfettin Üstünsoy², Ferah Armutçu \\ ${ }^{1}$ Department of Nutrition and Dietetics, Şifa University Faculty of Medicine, İzmir, Turkey \\ ${ }^{2}$ Department of Biochemistry, Fatih University Faculty of Medicine, İstanbul, Turkey \\ ${ }^{3}$ Department of Biochemistry, Cerrahpaşa Faculty of Medicine, İstanbul University, İstanbul, Turkey
}

Background: Metabolic syndrome (MetS) and obesity are serious health problems in the World, including Turkey. Contemporary studies have suggested a meaningful association between insulin resistance (IR), MetS parameters, and thyroid function tests.

Aims: We aimed to elucidate the impact of fat distribution on the anthropometric and laboratory parameters, especially indices of MetS, IR and thyroid function, in obese women.

Study Design: Cross-sectional study.

Methods: Anthropometric measurements of all participants and biochemical tests in their serum samples were performed.

Results: Weight, waist circumference (WC), body mass index (BMI), and other parameters of fat distribu- tion were significantly increased in all obese compared to control subjects; but there was no significant difference between central and peripheral obese groups. The central obese group had significantly higher insulin levels, components of MetS, the ratio free triiodothyronine (fT3) to free thyroxin fT4, and fT4 than those of peripheral obese and control groups.

Conclusion: Elevated triglyceride, glucose and insulin levels may be associated with increased IR, which in turn is related to MetS. Body fat composition may affect thyroid tests in the obese; the changes in fT3/fT4 could be the consequence of fat distribution.

Keywords: Anthropometry, obesity, Insulin resistance, metabolic syndrome, thyroid function
Obesity is a complex disorder in which excess body fat has accumulated excessively so that it may have an adverse effect on health, leading to increased disease incidence and decreased life expectancy. According to fat distribution, obesity is classified central (android) and peripheral (gynoid) type $(1,2)$. In the central type of obesity, the fat occupies the abdominal region of subjects. In the peripheral type, fat is accumulated around the hip and thigh areas; this means that the hips are almost rounded and the buttocks look larger compared to normal sub- jects. Central obese are more at risk of having diseases related to obesity such as type 2 diabetes, metabolic syndrome (MetS) and heart disease. In addition, the possibility of developing cardiovascular diseases, gout manifested as hypertension and the majority of cancers are linked to the central-type fat distribution. Central obesity can also be shown in some other parts of the body's upper trunk like the upper chest nape area of the neck, and even the shoulders. Central obese individuals have been known to be more vulnerable to diseases associated with

Address for Correspondence: Dr. Şükrü Aras, Department of Nutrition and Dietetics, Şifa University Faculty of Medicine, İzmir, Turkey

Phone: +90 5332413838 e-mail: sukruaras@gmail.com

Received: 20.01.2015 Accepted: 27.04.2015 • DOI: 10.5152/balkanmedj.2015.151218

Available at www.balkanmedicaljournal.org

Cite this article as:

Aras Ş, Üstünsoy S, Armutçu F. Indices of central and peripheral obesity; anthropometric measurements and laboratory parameters of metabolic syndrome and thyroid function.

Balkan Med J 2015;32:414-20 
obesity, whereas there is proof that peripheral fat distribution may be protective (3-5). Obesity is well-defined by using body mass index (BMI), a quantification obtained by dividing a person's weight by the square of the person's height. An adult who has a BMI of $25-30 \mathrm{~kg} / \mathrm{m}^{2}$ is defined as overweight, and an adult with a BMI $>30$ is considered obese (6). On the other hand, with the current increase in the prevalence of obesity, the study of IR and body composition has become an important area of research in public health (7). BMI is widely used as an anthropometric estimate of general adiposity, but failures in the identification of differences in body composition and distribution limit the usefulness of BMI (8). The association of obesity and IR is an extensive clinical condition, and insulin resistance (IR) also integrates these pathologies. Moreover, recent new studies have shown a relation between thyroid function tests and MetS parameters $(9,10)$. The aim of our study was to explore the relationship or differences between anthropometric indices that assess central obesity and peripheral obesity, and the relationship among IR, MetS and thyroid function in female obese and healthy control subjects.

\section{MATERIALS AND METHODS}

Participants of this study were enrolled in the Department of Internal Medicine, Division of Endocrinology, Metabolism and Nutrition outpatient clinics. The exclusion criteria were as follows: subjects who did not agree, patients with a history of diabetes mellitus, cardiovascular, hepatic or renal disease, and patients who were being treated with anti-hypertensive and -hyperlipidemic medications. Body weight and height were measured in all participating women, and having over $30 \mathrm{~kg}$ of weight was an inclusion criterion for obese persons. After the eligibility assessment for the study, fifty female obese persons, twenty peripheral and thirty central obese, and twenty female vigorous control subjects were included in the study. The study protocol was approved by the local ethical committee, and all procedures were performed in agreement with the general recommendations of the Declaration of Helsinki (11). In addition, all participants signed an informed consent. Following physical examination, height and weight were measured twice by standard methods, and the mean of the paired values was computed. Participants were weighed to the nearest $0.1 \mathrm{~kg}$ on a single calibrated electronic scale. Height was evaluated as the average of three measurements to the nearest $0.1 \mathrm{~cm}$ on a single calibrated wall-mounted Harpenden stadiometer. BMI of the participants was calculated as weight (in $\mathrm{kg}$ ) divided by height (in meters ${ }^{2}$ ) and BMI was represented as a standard deviation score. Waist circumference (WC) measurements were obtained with a plastic tape measure at the level of the iliac crest and umbilicus; the maximum hip circumference (HC) was measured. HC assessment was also performed using a measuring tape set down horizontally at the place of utmost boundary over the buttocks. All measurements were recorded at the end of expiration with the subject standing. The sagittal and transverse abdominal diameters (height) were measured using a portable, sliding-beam caliper for the estimation if abdominal adiposity. Skinfold thickness (ST) was measured by the same caliper at standardized skin pinch points to determine the subcutaneous fat layer thickness $(3,12)$. Several methods were used for the measurements of body composition and body fat distribution, such as computed tomography and dual-energy X-ray absorptiometry. However, bioelectrical body impedance analysis (BIA) is a simple, lowcost, safe and accurate method for body composition analysis. Body composition was measured using a four-terminal bioimpedance analyzer (Bodystat 1500, Douglas, England), using previously described procedures and anatomical sites (13). Blood pressure (BP) was recorded in the sitting position after 5 min of rest in a quiet environment using a mercury sphygmomanometer. Systolic and diastolic BP were averaged using the last two measurements at 5-min intervals.

Venous blood samples of the subjects were taken and placed in polystyrene tubes by venipuncture of the antecubital vein while patients rested in sitting position at morning time (between 08.00 and 09.00 ), after a 12 -h fasting period. The blood samples were transported to the routine laboratory within 1 $\mathrm{h}$ and centrifuged at $+4^{\circ} \mathrm{C}$ to remove serum $(1000=\mathrm{g}$ for 10 min). All biochemical (glucose, lipids, enzymes, and others) parameter levels were analyzed by Cobas Integra 800 analyzer (Roche Diagnostics, Geneva, Switzerland) in serum samples, but low-density lipoprotein (LDL) concentrations were calculated from the Friedewald formula. HbA1c analysis was performed in newly obtained samples by using high-performance liquid chromatography (HPLC) (Bio-Rad, Paris, France). Analyses were performed on fresh serum, whereas some fasting blood samples were centrifuged and frozen at $-20^{\circ} \mathrm{C}$ for insulin measurements. Insulin, thyroid-stimulating hormone (TSH), fT3 and fT4 hormone levels were also measured on serum samples by chemiluminescent enzyme immunoassay system (Immulate 2000, Deerfield, USA). Assays were performed according to the manufacturer's handbook with inter-assay and intra-assay coefficients of variation that did not exceed $6.4 \%$. Insulin resistance was estimated by homeostasis model assessment (HOMA) index for each participant and was calculated for subjects using the computer-driven HOMA-IR formula; serum insulin $(\mu \mathrm{IU} / \mathrm{mL}) \mathrm{x}$ glucose levels $(\mathrm{mg} / \mathrm{dL}) / 405$ (14); a cut-off limit of 2 was agreed for IR.

The Statistical Package for Social Sciences (SPSS 15.0) for Windows (SPSS Inc., Chicago, IL, USA) was utilized to analyze the data. Kruskal-Wallis test and Mann-Whitney U test 
for continuous variables were applied to examine the variance among groups if suitable. Pearson Chi-square test was utilized to investigate the categorical elements. Results were conveyed as mean \pm standard deviation of means for the parameters. $\mathrm{P}$ values less than 0.05 were considered statistically significant. Additionally, the relationship between variables were estimated by Pearson's and Spearman's rank correlation tests, and $p$ value $<0.05$ was noted significant.

\section{RESULTS}

As seen in Table 1, there was no difference between the ages of the groups. Weight, BMI and WC were significantly higher in central and peripheral obese than in healthy control subjects $(p<0.01)$. Except for $\mathrm{WC}$ and sagittal height, an insignificant difference was detected between the central and peripheral obese groups. Likewise, parameters of the Bodystat device were higher in obese groups, but there was no difference between central and peripheral obese groups (Table 2). As seen in Table 3, there were insignificant differences in glucose levels between all obese individuals and the control group. The central obese group had significantly higher insulin levels and statistically significant HOMA-IR levels compared to those of the peripheral obese and control groups. In terms of the number of laboratory variables, there were no differences between central and peripheral obese groups. However, it was observed that uric acid levels were significantly higher in the central obese group than in controls, as were BP measurements. As also shown in Table 4, the presence of three or more components of MetS was much more common in the central obese group. Similarly, thyroid function test (especially fT4 and fT3/ fT4) results were higher in the central obese group than in the peripheral obese and control groups. Due to the prevalence of MetS in obese people, between disease components with anthropometric and laboratory measurements correlation analysis was performed (Table 5). In all (n: 50) obese subjects, BMI was positively correlated with each component of MetS except for high-density lipoprotein (HDL). Similarly, other anthropometric measurements, such as total fat mass (FM), sagittal height and subscapular ST, were also positively correlated with this component $(\mathrm{p}<0.01)$. In addition, it was found that $\mathrm{WC}$, glucose and triglyceride levels were positively correlated with fT3/fT4.

\section{DISCUSSION}

Obesity has been known as a critical health problem pointing out the risk of several chronic diseases including meta-
TABLE 1. Age and anthropometric parameters of each group

\begin{tabular}{|c|c|c|c|}
\hline & $\begin{array}{c}\text { Control } \\
\text { group }(\mathrm{n}: 20) \\
(\text { mean } \pm \text { SD) }\end{array}$ & $\begin{array}{c}\text { Peripheral } \\
\text { obese (n: } 20) \\
(\text { mean } \pm \text { SD) }\end{array}$ & $\begin{array}{c}\text { Central } \\
\text { obese }(\mathrm{n}: 30) \\
(\text { mean } \pm \text { SD) }\end{array}$ \\
\hline Age & $33.75 \pm 3.70$ & $29.90 \pm 6.80^{\mathrm{ns}}$ & $32.73 \pm 4.60^{\mathrm{ns}, \mathrm{ns}}$ \\
\hline Height (cm) & $158.5 \pm 5.04$ & $162.1 \pm 4.89^{\text {ns }}$ & $161.2 \pm 6.34^{\mathrm{b}, \mathrm{ns}}$ \\
\hline Weight (kg) & 58. $96 \pm 5.72$ & $93.30 \pm 8.28^{\mathrm{a}}$ & $98.31 \pm 18.60^{\mathrm{b}, \mathrm{ns}}$ \\
\hline BMI $\left(\mathrm{kg} / \mathrm{m}^{2}\right)$ & $23.47 \pm 2.43$ & $35.76 \pm 2.60^{\mathrm{a}}$ & $37.84 \pm 5.83^{\mathrm{b}, \mathrm{ns}}$ \\
\hline $\mathrm{WC}(\mathrm{cm})$ & $75.35 \pm 7.27$ & $95.15 \pm 4.41^{\mathrm{a}}$ & $105.80 \pm 11.31^{\mathrm{b}, \mathrm{c}}$ \\
\hline $\mathrm{HC}(\mathrm{cm})$ & $99.4 \pm 5.04$ & $124.6 \pm 6.23^{\mathrm{a}}$ & $122.9 \pm 12.66^{\mathrm{b}, \mathrm{ns}}$ \\
\hline WHR & $0.76 \pm 0.05$ & $0.76 \pm 0.03^{\text {ns }}$ & $0.86 \pm 0.03^{\mathrm{b}, \mathrm{c}}$ \\
\hline Biceps ST (mm) & $13.00 \pm 3.93$ & $27.45 \pm 8.34^{\mathrm{a}}$ & $26.43 \pm 5.51^{\mathrm{b}, \mathrm{ns}}$ \\
\hline Triceps ST (mm) & $27.55 \pm 6.27$ & $44.10 \pm 7.40^{\mathrm{a}}$ & $42.77 \pm 5.50^{\mathrm{b}, \mathrm{ns}}$ \\
\hline Subscapular ST (mm) & $17.75 \pm 6.44$ & $47.15 \pm 6.03^{\mathrm{a}}$ & $51.70 \pm 9.36^{\mathrm{b}, \mathrm{ns}}$ \\
\hline Paraumblical ST (mm) & $31.10 \pm 10.95$ & $53.50 \pm 7.17^{\mathrm{a}}$ & $57.60 \pm 9.11^{\mathrm{b}, \mathrm{ns}}$ \\
\hline Suprailiac ST (mm) & $23.65 \pm 7.40$ & $47.55 \pm 8.09^{\mathrm{a}}$ & $50.80 \pm 7.69^{\mathrm{b}, \mathrm{ns}}$ \\
\hline Sagittal height (cm) & $16.10 \pm 1.91$ & $22.90 \pm 1.75^{\mathrm{a}}$ & $25.17 \pm 2.90^{\mathrm{b}, \mathrm{c}}$ \\
\hline Transverse height $(\mathrm{cm})$ & $23.85 \pm 1.45$ & $28.98 \pm 2.16^{\mathrm{a}}$ & $30.50 \pm 2.61^{\mathrm{b}, \mathrm{ns}}$ \\
\hline
\end{tabular}

a: peripheral obese group vs control group; ${ }^{\text {b}}:$ central obese group vs control group; ${ }^{\mathrm{ns}}$ (not significant): central obese group vs peripheral obese group (all $\mathrm{p}<0.001$ ) SD: standard deviation; BMI: body mass index; WC: waist circumference; HC: hip circumference; WHR: waist-to-hip ratio; ST: skinfold thickness

Statistical tests: Kruskal-Wallis and Mann-Whitney U tests

TABLE 2. Parameters of body composition estimated by the Bodystat device in control and obese groups

\begin{tabular}{lccc}
\hline & $\begin{array}{c}\text { Control } \\
\text { group (n: 20) } \\
(\text { mean } \pm \text { SD) }\end{array}$ & $\begin{array}{c}\text { Peripheral } \\
\text { obese (n: 20) } \\
(\text { mean } \pm \text { SD) }\end{array}$ & $\begin{array}{c}\text { Central } \\
\text { obese (n: 30) } \\
(\text { mean } \pm \text { SD) }\end{array}$ \\
\hline Total FM (\%) & $25.43 \pm 5.32$ & $40.59 \pm 3.22^{\mathrm{a}}$ & $41.93 \pm 5.16^{\mathrm{b}, \mathrm{ns}}$ \\
Total FM (kg) & $15.17 \pm 4.39$ & $38.01 \pm 5.68^{\mathrm{a}}$ & $41.95 \pm 13.32^{\mathrm{b}, \mathrm{ns}}$ \\
Total FFM tissue (\%) & $74.56 \pm 5.32$ & $59.41 \pm 3.22^{\mathrm{a}}$ & $58.06 \pm 5.16^{\mathrm{b}, \mathrm{ns}}$ \\
Total FFM tissue (kg) & $43.78 \pm 3.54$ & $55.29 \pm 4.14^{\mathrm{a}}$ & $56.33 \pm 6.33^{\mathrm{b} \text {, ns }}$ \\
Total water (\%) & $55.86 \pm 4.11$ & $43.01 \pm 2.74^{\mathrm{a}}$ & $42.89 \pm 3.49^{\mathrm{b}, \mathrm{ns}}$ \\
Total water $(\mathrm{kg})$ & $32.75 \pm 2.05$ & $40.02 \pm 3.35^{\mathrm{a}}$ & $41.33 \pm 5.28^{\mathrm{b}, \mathrm{ns}}$ \\
BMR (kCal) & $1480.30 \pm 85$ & $1751.7 \pm 108^{\mathrm{a}}$ & $1779.1 \pm 158^{\mathrm{b}, \mathrm{ns}}$ \\
\hline
\end{tabular}

a: peripheral obese group vs control group; ${ }^{\text {b: }}$ central obese group vs control group; ${ }^{\mathrm{c}}$ or ${ }^{\mathrm{ns}}$ : central obese group vs peripheral obese group (all $\mathrm{p}<0.001$ )

SD: standard deviation; FM: fat mass; FFM: fat-free-mass; BMR: basal metabolic rate

Statistical tests: Kruskal-Wallis and Mann-Whitney U tests

bolic and cardiovascular disorders. Various anthropometric measurements have been used to assess metabolic and cardiovascular risk, including BMI and percent body fat, as well as site specific measurements, such as peripheral or central fat and WC (15). Unlike peripheral obesity, central or abdominal obesity can be described by classical indices such as WC and waist-to-hip ratio (WHR) (16). Moreover, some newer obesity indices were also described including waist to height ratio, body adiposity index, and visceral adiposity index (17). The use of BMI and anthropometric measurements for diagnosing 
TABLE 3. Comparison of blood pressure measurements and biochemical parameters in the serum of control and obese groups

\begin{tabular}{|c|c|c|c|}
\hline & $\begin{array}{c}\text { Control } \\
\text { group }(\mathrm{n}: 20) \\
(\text { mean } \pm \mathrm{SD})\end{array}$ & $\begin{array}{c}\text { Peripheral } \\
\text { obese (n: } 20) \\
(\text { mean } \pm \text { SD) }\end{array}$ & $\begin{array}{c}\text { Central } \\
\text { obese }(\mathrm{n}: 30) \\
(\text { mean } \pm \text { SD) }\end{array}$ \\
\hline Systolic BP (mmHg) & $108.00 \pm 7.68$ & $116.00 \pm 10.46$ & $115.17 \pm 9.42^{\mathrm{b}, \mathrm{x}}$ \\
\hline Diastolic BP (mmHg) & $68.00 \pm 7.68$ & $77.50 \pm 6.39$ & $75.83 \pm 9.48^{\mathrm{b}, \mathrm{c}}$ \\
\hline Glucose (mg/dL) & $80.65 \pm 7.72$ & $86.60 \pm 9.06^{\mathrm{ns}}$ & $91.13 \pm 13.09^{\mathrm{b}, \mathrm{ns}}$ \\
\hline Triglyceride (mg/dL) & $83.00 \pm 40.16$ & $117.30 \pm 46.78^{x}$ & $155.97 \pm 67.2^{\mathrm{b}, \mathrm{ns}}$ \\
\hline Total cholesterol & $176.30 \pm 21.2$ & $177.80 \pm 27.42^{\mathrm{ns}}$ & $205.00 \pm 34.7^{\mathrm{b}, \mathrm{c}}$ \\
\hline HDL-cholesterol & $52.40 \pm 11.1$ & $45.25 \pm 6.3^{\mathrm{ns}}$ & $43.00 \pm 6.7^{\mathrm{b}, \mathrm{ns}}$ \\
\hline LDL-cholesterol & $104.10 \pm 16.5$ & $109.15 \pm 23.3^{\mathrm{ns}}$ & $128.63 \pm 27.7^{\mathrm{b}, \mathrm{c}}$ \\
\hline Urea (mg/dL) & $10.75 \pm 2.01$ & $12.10 \pm 3.09^{\mathrm{ns}}$ & $11.50 \pm 2.475^{\mathrm{ns}, \mathrm{ns}}$ \\
\hline Creatinine (mg/dL) & $0.71 \pm 0.1$ & $0.71 \pm 0.08^{\mathrm{ns}}$ & $0,72 \pm 0.115^{\mathrm{ns}, \mathrm{ns}}$ \\
\hline Uric aside $(\mathrm{mg} / \mathrm{dL})$ & $3.88 \pm 0.65$ & $4.40 \pm 0.74^{\mathrm{ns}}$ & $4.64 \pm 1.36^{\mathrm{x}, \mathrm{ns}}$ \\
\hline $\mathrm{CRP}(\mathrm{mg} / \mathrm{L})$ & $0.45 \pm 0.4$ & $0.61 \pm 0.43^{\mathrm{ns}}$ & $0.64 \pm 0.57^{\mathrm{ns}, \mathrm{ns}}$ \\
\hline $\operatorname{AST}(\mathrm{U} / \mathrm{L})$ & $16.8 \pm 3.05$ & $18.25 \pm 4.60^{\mathrm{ns}}$ & $18.53 \pm 4.59^{\text {ns, ns }}$ \\
\hline $\operatorname{ALT}(\mathrm{U} / \mathrm{L})$ & $16.1 \pm 4.55$ & $20.70 \pm 8.26^{\mathrm{ns}}$ & $21.13 \pm 8.75^{\mathrm{ns}, \mathrm{ns}}$ \\
\hline GGT (U/L) & $14.1 \pm 3.8$ & $17.11 \pm 4.60^{\mathrm{ns}}$ & $21.55 \pm 9.89^{\mathrm{b}, \mathrm{ns}}$ \\
\hline HbAlc (\%) & $5.28 \pm 0.16$ & $5.21 \pm 0.16^{\mathrm{ns}}$ & $5.42 \pm 0.32^{\mathrm{ns}, \mathrm{ns}}$ \\
\hline Insulin $(\mu \mathrm{IU} / \mathrm{mL})$ & $6.37 \pm 2.75$ & $9.96 \pm 3.72^{\mathrm{a}}$ & $15.25 \pm 7.45^{\mathrm{b}, \mathrm{ns}}$ \\
\hline HOMA-IR & $1.28 \pm 0.6$ & $2.18 \pm 1.03^{\mathrm{a}}$ & $3.52 \pm 2.03^{\mathrm{b}, \mathrm{ns}}$ \\
\hline TSH (mIU/mL) & $1.78 \pm 1.14$ & $2.05 \pm 1.27^{\mathrm{ns}}$ & $2.09 \pm 1.34^{\mathrm{ns}, \mathrm{ns}}$ \\
\hline fT3 $(\mathrm{pg} / \mathrm{mL})$ & $4.21 \pm 0.44$ & $4.67 \pm 0.63^{\mathrm{ns}}$ & $4.72 \pm 0.56^{\mathrm{b}, \mathrm{ns}}$ \\
\hline fT4 (ng/dL) & $15.37 \pm 1.52$ & $13.85 \pm 1.35^{\mathrm{a}}$ & $13.78 \pm 1.90^{\mathrm{b}, \mathrm{ns}}$ \\
\hline fT3/ fT4 & $0.28 \pm 0.02$ & $0.34 \pm 0.07^{\mathrm{a}}$ & $0.35 \pm 0.05^{\mathrm{b}, \mathrm{ns}}$ \\
\hline \multicolumn{4}{|c|}{$\begin{array}{l}\text { a: peripheral obese group vs control group; }{ }^{\text {b: }} \text { central obese group vs control group; } \\
\text { c } \text { or }^{\text {ns: }} \text { central obese group vs peripheral obese group (in all } \mathrm{p}<0.01 \text {, except for } \mathrm{x} ; \mathrm{p} \\
<0.05 \text { ) } \\
\text { SD: standard deviation; BP: blood pressure; HDL: high-density lipoprotein; } \\
\text { LDL: low-density lipoprotein; CRP: C-reactive protein; AST: aspartate transaminase; } \\
\text { ALT: alanine transaminase; GGT: gamma-glutamyl transferase; HOMA-IR: homeo- } \\
\text { stasis model assessment-insulin resistance; TSH: thyroid-stimulating hormone; } \\
\text { fT3: free triiodothyronine; fT4: free thyroxin } \\
\text { Statistical tests: Kruskal-Wallis and Mann-Whitney U tests }\end{array}$} \\
\hline
\end{tabular}

obesity is well documented in the literature, as they have good clinical feasibilities (4). There is no agreement on the best anthropometric measurement for this, since a good indicator of the location of body fat should be associated with risk markers for metabolic diseases regardless of sex, age, and total adiposity. Hence, due to the limitations of central or peripheral body fat, other anthropometric measurements are used in epidemiological studies, such as WC, WHR and ST (18). In this study, all parameters of anthropometric measurements both peripheral and central obesity groups were higher than in the healthy control group. However, only two parameters with differences, WC and abdominal height, were statistically significant among peripheral and central obese groups. Central obesity is characterized as excess fat accumulation in the abdominal area, whereas peripheral obesity is the accumulation of ex-
TABLE 4. Presence of metabolic syndrome components among the study groups, according to the NCEP-ATP III criteria (all participants; women)

\begin{tabular}{|c|c|c|c|c|}
\hline & $\begin{array}{l}\text { Control } \\
\text { group } \\
(\mathrm{n}: 20)\end{array}$ & $\begin{array}{c}\text { Peripheral } \\
\text { obese } \\
\text { (n: } 20)\end{array}$ & $\begin{array}{l}\text { Central } \\
\text { obese } \\
(\mathrm{n}: 30)\end{array}$ & \\
\hline $\mathrm{WC}(>88 \mathrm{~cm})$ & 2 & 19 & 30 & $\mathrm{p}<0.001$ \\
\hline $\begin{array}{l}\text { High triglyceride } \\
(\geq 150 \mathrm{mg} / \mathrm{dL})\end{array}$ & 1 & 5 & 15 & $\mathrm{p}<0.01$ \\
\hline $\begin{array}{l}\text { Low HDL-Cholesterol } \\
(<50 \mathrm{mg} / \mathrm{dL})\end{array}$ & 9 & 15 & 26 & $\mathrm{p}<0.01$ \\
\hline $\begin{array}{l}\text { Fasting blood glucose } \\
(\geq 110 \mathrm{mg} / \mathrm{dL})\end{array}$ & - & 1 & 2 & Ns \\
\hline $\begin{array}{l}\text { Hypertension } \\
(\geq 130 / 85 \mathrm{mmHg})\end{array}$ & - & 1 & 1 & Ns \\
\hline $\begin{array}{l}\text { Presence of } \geq 3 \text { criteria } \\
\text { within the group }\end{array}$ & - & 1 & 5 & $\mathrm{p}<0.001$ \\
\hline
\end{tabular}

TABLE 5. Pearson correlations between parameters of metabolic syndrome and some anthropometrics measurements (between all obese participants; $n$ : 50 and healthy control subjects; n: 20)

\begin{tabular}{lccccc}
\hline & $\begin{array}{c}\text { Waist } \\
\text { circumference }\end{array}$ & Glucose & Triglyceride & $\begin{array}{c}\text { HDL- } \\
\text { Cholesterol }\end{array}$ & $\begin{array}{c}\text { Systolic } \\
\text { BP }\end{array}$ \\
\hline BMI & $\mathrm{r}=0.492 ;$ & $\mathrm{r}=0.346 ;$ & $\mathrm{r}=0.453 ;$ & $\mathrm{r}=-0.389 ;$ & $\mathrm{r}=0.393 ;$ \\
& $\mathrm{p}<0.001$ & $\mathrm{p}<0.003$ & $\mathrm{p}<0.001$ & $\mathrm{p}<0.001$ & $\mathrm{p}<0.001$ \\
WHR & $\mathrm{r}=0.703 ;$ & $\mathrm{r}=0.214 ;$ & $\mathrm{r}=0.462 ;$ & $\mathrm{r}=-0.422 ;$ & $\mathrm{r}=0.146 ;$ \\
& $\mathrm{p}<0.001$ & $\mathrm{p}=0.075$ & $\mathrm{p}<0.001$ & $\mathrm{p}<0.001$ & $\mathrm{p}=0.229$ \\
Total FM & $\mathrm{r}=0.936 ;$ & $\mathrm{r}=0.337 ;$ & $\mathrm{r}=0,451 ;$ & $\mathrm{r}=-0.335 ;$ & $\mathrm{r}=0.391 ;$ \\
& $\mathrm{p}<0.001$ & $\mathrm{p}<0.004$ & $\mathrm{p}<0.001$ & $\mathrm{p}<0.005$ & $\mathrm{p}<0.001$ \\
Subscapular & $\mathrm{r}=0.887 ;$ & $\mathrm{r}=0.418 ;$ & $\mathrm{r}=0.473 ;$ & $\mathrm{r}=-0.489 ;$ & $\mathrm{r}=0.350 ;$ \\
ST & $\mathrm{p}<0.001$ & $\mathrm{p}<0.001$ & $\mathrm{p}<0.001$ & $\mathrm{p}<0.001$ & $\mathrm{p}<0.003$ \\
Sagittal & $\mathrm{r}=0.917 ;$ & $\mathrm{r}=0.374 ;$ & $\mathrm{r}=0.501 ;$ & $\mathrm{r}=-0.430 ;$ & $\mathrm{r}=0.390 ;$ \\
height & $\mathrm{p}<0.001$ & $\mathrm{p}<0.001$ & $\mathrm{p}<0.001$ & $\mathrm{p}<0.001$ & $\mathrm{p}<0.001$ \\
HOMA-IR & $\mathrm{r}=0.522 ;$ & $\mathrm{r}=0.658 ;$ & $\mathrm{r}=0.363 ;$ & $\mathrm{r}=-0.440 ;$ & $\mathrm{r}=0.212 ;$ \\
& $\mathrm{p}<0.001$ & $\mathrm{p}<0.001$ & $\mathrm{p}<0.002$ & $\mathrm{p}<0.001$ & $\mathrm{p}=0.078$ \\
Uric acid & $\mathrm{r}=0.305 ;$ & $\mathrm{r}=0.212 ;$ & $\mathrm{r}=0.353 ;$ & $\mathrm{r}=-0.196 ;$ & $\mathrm{r}=0.040 ;$ \\
& $\mathrm{p}<0.010$ & $\mathrm{p}=0.078$ & $\mathrm{p}<0.003$ & $\mathrm{p}=0.104$ & $\mathrm{p}=0.739$ \\
fT3/fT4 & $\mathrm{r}=0.560 ;$ & $\mathrm{r}=0.304 ;$ & $\mathrm{r}=0.324 ;$ & $\mathrm{r}=-0.376 ;$ & $\mathrm{r}=0.220 ;$ \\
ratio & $\mathrm{p}<0.001$ & $\mathrm{p}<0.011$ & $\mathrm{p}<0.006$ & $\mathrm{p}<0.001$ & $\mathrm{p}=0.067$ \\
\hline
\end{tabular}

BMI: body mass index; WHR: waist-to-hip ratio; FM: fat mass; ST: skinfold thickness; HOMA-IR: homeostasis model assessment-insulin resistance; fT3: free triiodothyro; fT4: free thyroxin

Statistical tests: Pearson's and Spearman's rank correlation tests

cess fat in the buttocks, hips and thighs. Therefore, a couple of methods have been invented to estimate adiposity such as ST. Although determining adiposity in children is particularly difficult, Torun et al. showed that childhood obesity was significantly different according to BMI (8). We have found that mean WC (more than WHR) increased across obesity (BMI) classes in both obese groups. Similar results were reported by 
Kamadjeu et al. (19) in the adult metropolitan population of Cameroon in both genders. According to their study results, WC was found to be powerfully correlated with BMI but exhibited an average correlation with WHR in men and women adults. However, we have observed a strong correlation between WC and WHR. Even so, it is said that WC, as an index of central obesity, is a good tool and guide for use in clinical practice and epidemiological studies. Bouchard (20) reported that BMI, FM and WC are identically well correlated with computerized tomography-assessed abdominal visceral fat. In this study, when all participants were considered together, interestingly subscapular ST and BMI measurements showed quite significant accuracy. Bioelectrical body impedance analysis is an easy, non-invasive method to estimate aspects such as FM, fat-free mass and total body water. It is possible to make the distinction between central and peripheral obesity with this device $(21,22)$. All parameters of BIA in the peripheral and central obese groups were found to be higher than in the healthy control group, whereas the same parameters were not significantly different between the peripheral and central obese groups. Likewise, Berker et al. (21) found that anthropometric variables were indistinguishable between genders, but WHR quantifications were higher in males than in females. In addition, the measurements methods best correlating with visceral fat area by computed tomography were BIA in male and female obese persons. Fundamentally, obesity originates from eating too much or the lack of success by the body to consume energy for everyday activities; as a result, the extra energy is reserved as fat tissue in the organism. Excess body fat may increase the risk of metabolic alterations such as dyslipidemia, IR, pre-diabetes and hypertension in overweight people (23). Subcutaneous thigh adipose tissue is associated with MetS in obese men and women. In one study, it was found that patients with MetS had notably more abdominal visceral fat compared to subcutaneous fat. Moreover, per standard deviation higher of visceral fat, the odds of developing MetS increased in women (24). Similarly, another study reported that the odds of having two or more MetS clinical disorders increased with incremental increases in anthropometric measures (25). In this study, the results showed that obese participants have MetS components: high BP, WC, triglyceride and glucose levels, and lower HDL-C levels. According to the Adult Treatment Panel III (ATP III) report criteria, obese subjects with three or more of these metabolic abnormalities are considered to have MetS $(15,23)$. Additionally, it is found that the central obese group showed dyslipidemia, and components of IR such as higher insulin levels and HOMA-IR indexes. In this study, the number of subjects with $\geq 2$ HOMA-IR was higher in the central obese group. These findings support the notion of central obesity as a cause of IR. Body fat distribution is associated with IR and type-2 diabetes. Visceral adipose tissue (central obesity) places individuals at a greater risk of MetS disorders than adipose tissue located in the lower body or subcutaneously (26). However, alternate anthropometric measures of abdominal fat appear to be better predictors of IR and type-2 diabetes than BMI (27). In addition to differences in adipose distribution, which also tend to affect hypertension, newly diagnosed hypertensives in the study had a large WC, high BMI, and high fasting glucose and insulin levels (28).

On the other hand, thyroid hormone disorders are associated with changes in body composition, and obesity may have an impact on the levels of thyroid hormones as well as the risk of MetS in women $(9,29)$. Tarcin et al. (30) showed that MetS positive patients had significantly higher fasting glucose, triglyceride, fT4, BP, and lower HDL and fT3/fT4 ratio than MetS negative patients. In our study, interestingly, MetS parameters, except systolic BP, were correlated with the fT3/fT4 ratio, (HDL negatively), significantly. This association might be defined by stabilizing effects of total T3, and probably fT4, on energy expenditure and thermogenesis in obese people. Moreover, in obese women, lower fT4 levels and consequently a higher fT3/fT4 ratio were found to be steadily related to miscellaneous markers of critical metabolic profile and cardiovascular risk (31). Additionally, Bilgin and Pirgon (32) reported that obese adolescents with steatohepatitis had elevated values for fT3/fT4 ratio. Ortega et al. (33) suggested that fT3 was related with insulin secretion in euthyroid subjects, and T3 levels may be involved in the regulation of insulin secretion. In another study, it was proposed that alterations in thyroid hormones could be the result rather than the source of the increasing weight (34). One of the limitations of the present study is the inclusion of only female participants rather than both sexes. The other is that the study group itself contained a small group of obese subjects. It is therefore crucial to substantiate these findings in larger obesity groups.

In conclusion, our study results suggest that there was no difference between central and peripheral obese subjects in terms of anthropometric measurements. Elevated triglyceride, glucose and insulin levels may be associated with increased IR, which in turn is related to metabolic syndrome. With the results of the present study, it can be concluded that MetS components and IR represented by HOMA indexes may be related to components of MetS, especially in central obese women. Body fat composition may affect thyroid function in obese subjects; the changes in the fT 4 and fT3/fT 4 could be the consequence of the fat distribution.

Ethics Committee Approval: Ethics committee approval was received for this study from the ethics committee of İstanbul University, İstanbul Faculty of Medicine. 
Informed Consent: Written informed consent was obtained from patients who participated in this study.

Peer-review: Externally peer-reviewed.

Author contributions: Concept - Ş.A.; Design - Ş.A., F.A.; Supervision - F.A.; Resource - Ş.A.; Materials - Ş.A.; Data Collection \&/or Processing - Ş.A., F.A.; Analysis \&/or Interpretation - S.A.; Literature Search - S.Ü., S.A.; Writing - Ş.A., F.A., S.Ü.; Critical Reviews - Ş.A., F.A., S.Ü.

Conflict of Interest: No conflict of interest was declared by the authors.

Financial Disclosure: The authors proclaimed that this study has not received any financial support.

\section{REFERENCES}

1. Haslam DW, James WP. Obesity. Lancet 2005;366:1197-209. [CrossRef]

2. James WP. The epidemiology of obesity: the size of the problem. J Intern Med 2008;263:336-52. [CrossRef]

3. Chnag SH, Beason TS, Hunleth JM, Colditz GA. A systematic review of body fat distribution and mortality in older people. Maturitas 2012;72:175-91. [CrossRef]

4. Mooney SJ, Baecker A, Rundle AG. Comparison of anthropometric and body composition measures as predictors of components of the metabolic syndrome in a clinical setting. Obes Res Clin Pract 2013;7:e55-66. [CrossRef]

5. Lee MJ, Wu Y, Fried SK. Adipose tissue heterogeneity: implication of depot differences in adipose tissue for obesity complications. Mol Aspects Med 2013;34:1-11. [CrossRef]

6. Bennasar-Veny M, Lopez-Gonzalez AA, Tauler P,Cespedes ML, Vicente-Herrero T, Yanez A, et al. Body adiposity index and cardiovascular health risk factors in Caucasians: a comparison with the body mass index and others. PLoS One 2013;8:e63999. [CrossRef]

7. Geer EB, Shen W. Gender differences in insulin resistance, body composition, and energy balance. Gend Med 2009;6(Suppl 1):60-75. [CrossRef]

8. Torun E, Cakir E, Ozgüç F, Ozgen IT. The Effect of Obesity Degree on Childhood Pulmonary Function Tests. Balkan Med J 2014;31:235-8. [CrossRef]

9. Topsakal S, Yerlikaya E, Akin F, Kaptanoglu B, Erürker T. Relation with HOMA-IR and thyroid hormones in obese Turkish women with metabolic syndrome. Eat Weight Disord 2012;17:e57-61. [CrossRef]

10. Ren R, Jiang X, Zhang X, Guan Q, Yu C, Li Y, et al. Association between thyroid hormones and body fat in euthyroid subjects. Clin Endocrinol (Oxf) 2014;80:585-90. [CrossRef]

11. Carlson RV, Body KM, Webb DJ. The revision of the Declaration of Helsinki: past, present and future. Br J Clin Pharmacol 2004;57:695-713. [CrossRef]
12. Semiz S, Ozgören E, Sabri N. Comparison of ultrasonographic and anthropometric methods to assess body fat in childhood obesity. Int J Obes (Lond) 2007;31:53-8. [CrossRef]

13. Buchholz AC, Bartok C, Schoeller DA. The validity of bioelectrical impedance models in clinical populations. Nutr Clin Pract 2004;19:433-46. [CrossRef]

14. Stumvoll M, Mitrakou A, Pimenta W, Jenssen T, Yki-Jarvinen $\mathrm{H}$, Van Haeften T, et al. Use of the oral glucose tolerance test to assess insulin release and insulin sensitivity. Diabetes Care 2000;23:295-301. [CrossRef]

15. Expert Panel on Detection, Evaluation, and Treatment ofHigh Blood Cholesterol in Adults. Executive Summary ofThe Third Report of The National Cholesterol EducationProgram (NCEP) Expert Panel on Detection, Evaluation, And Treatment of High Blood Cholesterol In Adults (AdultTreatment Panel III). JAMA 2001;285:2486-97. [CrossRef]

16. Canoy D, Wareham N, Luben R, Welch A, Bingham S, Day N, et al. Serum lipid concentration in relation to anthropometric indices of central and peripheral fat distribution in 20,021 British men and women: results from the EPIC-Norfolk population-based cohort study. Atherosclerosis 2006;189:420-7. [CrossRef]

17. Cornier MA, Despres JP, Davis N, Grossniklaus DA, Klein S, Lamarche B, et al. Assessing adiposity: a scientific statement from the American Heart Association. Circulation 2011;124:1996-2019. [CrossRef]

18. Daniels SR, Khoury PR, Morrison JA. Utility of Different Measures of Body Fat Distribution in Children and Adolescents. Am J Epidemiol 2000;152:1179-84. [CrossRef]

19. Kamadjeu RM, Edwards R, Atanga JS, Kiawi EC, Unwin N, Mbanya JC. Anthropometry measures and prevalence of obesity in the urban adult population of Cameroon: an update from the Cameroon Burden of Diabetes Baseline Survey. BMC Public Health 2006;6:228. [CrossRef]

20. Bouchard C. BMI, fat mass, abdominal adiposity and visceral fat: where is the 'beef'? Int J Obes (Lond) 2007;31:1552-3. [CrossRef]

21. Berker D, Koparal S, Işik S, Pasaoglu L, Aydin Y, Erol K, et al. Compatibility of different methods for the measurement of visceral fat in different body mass index strata. Diagn Interv Radiol 2010;16:99-105.

22. Varady KA, Santosa S, Jones PJ. Validation of hand-held bioelectical impedance analysis with magnetic resonance imaging fort the assessment of body composition in overweight women. Am J Hum Biol 2007;19:429-33. [CrossRef]

23. Armutcu F, Ataymen M, Atmaca H, Gurel A. Oxidative stress markers, C-reactive protein and heat shock protein levels in subjects with metabolic syndrome. Clin Chem Lab Med 2008:46;785-90. [CrossRef]

24. Koster A, Stenholm S, Alley DE, Kim LJ, Simonsick EM, Kanaya AM, et al. Body fat distribution and inflammation among obese older adults with and without metabolic syndrome. Obesity (Silver Spring) 2010;18:2354-61. [CrossRef]

25. Huang KC, Lee MS, Lee SD, Chang YH, Lin YC, Tu SH, et al. Obesity in the elderly and its relationship with cardiovascular risk factors in Taiwan. Obes Res 2005;13:170-8. [CrossRef] 
26. Despres JP. Body fat distribution and risk of cardiovascular disease: an update. Circulation 2012;126:1301-13. [CrossRef]

27. Woo J, Ho SC, Yu AL, Sham A. Is waist circumference a useful measure in predicting health outcomes in the elderly? Int J Obes Relat Metab Disord 2002;26:1349-55. [CrossRef]

28. Wu CH, Yao WJ, Lu FH, Yang YC, Wu JS, Chang CJ. Sex differences of body fat distribution and cardiovascular dysmetabolic factors in old age. Age Ageing 2001;30:331-6. [CrossRef]

29. Iacobellis G, Ribaudo MC, Zappaterreno A, Iannucci CV, Leonetti F.Relationship of thyroid function with body mass index, leptin, insulin sensitivity and adiponectin in euthyroid obese women. Clin Endocrinol 2005;62:487-91. [CrossRef]

30. Tarcin O, Abanonu GB, Yazici D, Tarcin O. Association of metabolic syndrome parameters with TT3 and FT3/FT4 ratio in obese Turkish population. Metab Syndr Relat Disord 2012;10:137-42. [CrossRef]
31. Roef GL, Rietzschel ER, Van Daele CM, Taes YE, De Buyzere ML, Gillebert TC, et al. Triiodothyronine and free thyroxine levels are differentially associated with metabolic profile and adiposity-related cardiovascular risk markers in euthyroid middle-aged subjects. Thyroid 2014;24:223-31. [CrossRef]

32. Bilgin H, Pirgon O. Thyroid function in obese children with non-alcoholic fatty liver disease. $J$ Clin Res Pediatr Endocrinol 2014;6:152-7. [CrossRef]

33. Ortega E, Koska J, Pannacciulli N, Bunt JC, Krakoff J. Free triiodothyronine plasma concentrations are positively associated with insulin secretion in euthyroid individuals. Eur J Endocrinol 2008;158:217-21. [CrossRef]

34. Soriguer F, Valdes S, Morcillo S, Esteva I, Almaraz MC, de Adana MS, et al. Thyroid hormone levels predict the change in body weight: a prospective study. Eur J Clin Invest 2011;41:1202-9. [CrossRef] 